\title{
IMPACT OF THE CHRISTCHURCH EARTHQUAKES ON THE ELECTRICAL POWER SYSTEM INFRASTRUCTURE
}

\author{
Andrew Massie ${ }^{1}$ \& Neville R. Watson ${ }^{2}$
}

\begin{abstract}
SUMMARY
This paper gives a brief summary of the performance of the electrical infrastructure in the earthquakes that struck Christchurch and surrounding regions in 2011, with particular reference to the 22 February 2011 earthquake which was the most devastating.
\end{abstract}

\section{INTRODUCTION}

Christchurch has experienced three major earthquakes, and approximately 10 moderate and >7,000 minor earthquakes since 4 September 2010. The affects of the initial earthquake centred in Greendale/Darfield area on 4 September and its effects on electrical infrastructure have been discussed [1]. Therefore this paper will discuss the impact of the subsequent earthquakes on the electrical Infrastructure, particularly the 6.3 earthquakes on 22 February 2011 and 13 June 2011.

Orion N.Z. Ltd is the Lines company that owns the distribution system in Christchurch and a large part of Canterbury. Orion has approximately 193,000 customer connections, a peak demand of $616 \mathrm{MW}$ and delivers 3,308 $\mathrm{GWh}$ annually. Orion tender out their contracting work and one major service provider is the contracting company Connetics, which is an Orion owned company. An overview of the Orion electrical distribution system is given in Fig. 1.

\section{THE SEISMIC EVENT}

Although the 22 February 2011 earthquake was only magnitude 6.3 on the Richter scale compared to the 7.1 magnitude earthquake on 4 September 2010, the position of the epicentre, the depth, the acceleration experienced and ground conditions, combined to produce far more devastation than would be expected for this magnitude event. This attributed to the recently discovered physical phenomena where the weaker upper layers "slap" against the lower layers. Moreover, the orientation of the rupture under the northern edge of the Port Hills was such that most of the energy was directed north-west towards the city [2].

\section{DAMAGE TO THE DISTRIBUTION NETWORK $\left(22^{\mathrm{ND}}\right.$ FEBRUARY 2011)}

The damage to electrical infrastructure can be attributed to four aspects:

- Acceleration (Ground shaking)

- Liquefaction

- Lateral spread

- Rockfalls/landslides/falling debris from building collapse

The 22 February 2011 earthquake had approximately 10 times the impact of the earthquake on 4 September 2010 (based on

\footnotetext{
${ }^{1}$ CPIT, Christchurch, New Zealand

${ }^{2}$ University of Canterbury, Christchurch, New Zealand
}

time to restore $90 \%$ of customers). It took 10 days to get $90 \%$ of power on compared with 1 day for $4^{\text {th }}$ September earthquake. 629 million customer minutes were lost. Fig. 2 shows the areas still without power one day after the $22^{\text {nd }}$ February earthquake.

700 Supply Industry workers from all over New Zealand and Australia contributed more than 200,000 people hours to repairing the network.

The damage that incurred was:

- $50 \%$ of $66 \mathrm{kV}$ cables ( $30 \mathrm{~km}$ out of a total of $60 \mathrm{~km}$ )

- 4 of 314 substations severely damaged

- $15 \%$ of $11 \mathrm{kV}$ cables damaged $(330 \mathrm{~km}$ out of a total of $2,200 \mathrm{~km})$

- $1000+$ faults

- Some damage to local substations $(11 \mathrm{kV} / 400 \mathrm{~V})$

- Some damage (cracked insulators and poles affected by liquefaction)

- $1 \%$ of LV cables damaged

- Electrical system in badly damaged buildings

- Administration building including Control Centre badly damaged.

\section{Substation Damage}

Of the 314 substations, 51 are Zone substations, 1 zone substation was lost to liquefaction (New Brighton) (Fig. 3) and 1 zone substation/switchyard lost to liquefaction (Pages Road).

Of the remainder, 263 Orion owned building substations, three were severely damaged. They were:

- One substation severely damaged by shaking (St Andrews Hill)

- One substation damaged by boulder (Wakefield Ave Nth) (shown in Fig. 4)

- One substation infill wall failed (Port Hills Rd)

The seismic strengthening performed by Orion over the last 10 years clearly showed its benefit. The building structures performed very well and if they had not been strengthened the collapses would have damaged a lot more electrical infrastructure. This is clearly shown in Fig. 5 where the Orion part of the structure has been strengthened while the water department side has not, and collapsed. 


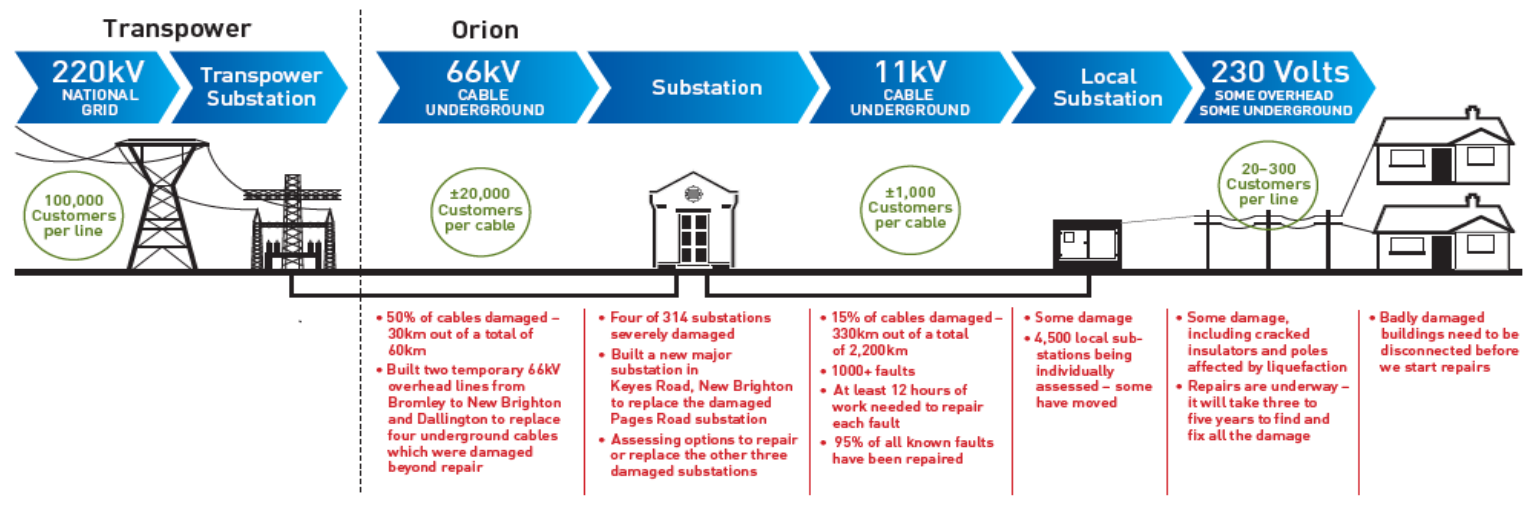

Figure 1: Overview of Damage to the electricity network since the February earthquake (courtesy Orion N.Z. Ltd).

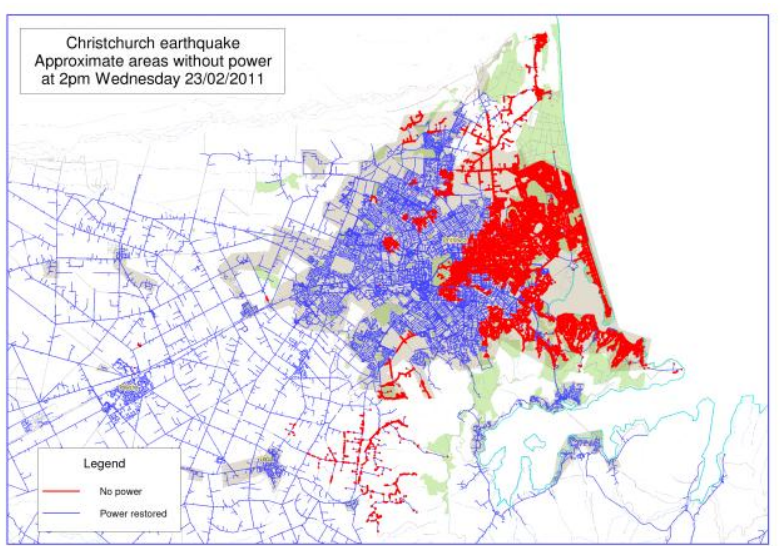

Figure 2: Electrical Outage Map one day after $22^{\text {nd }}$ February Earthquake (courtesy Orion N.Z. Ltd).

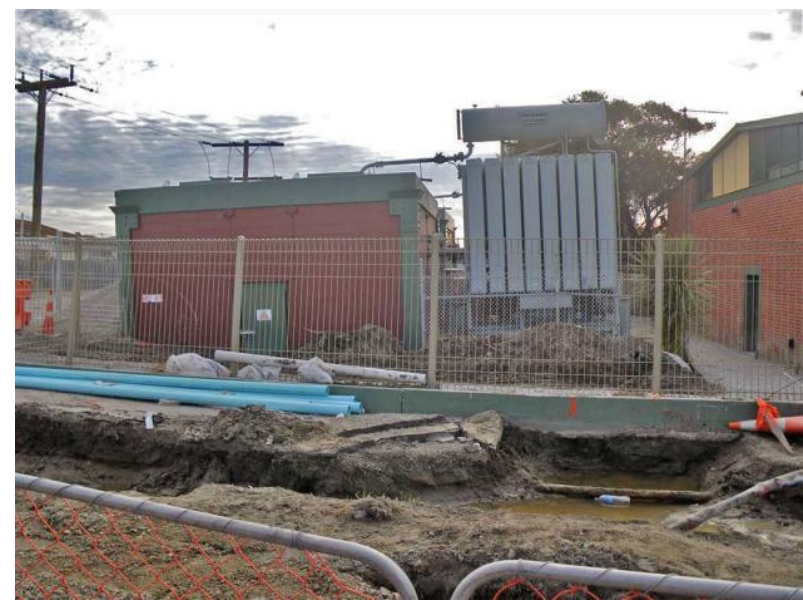

Figure 3: Liquefaction damage (New Brighton Substation).

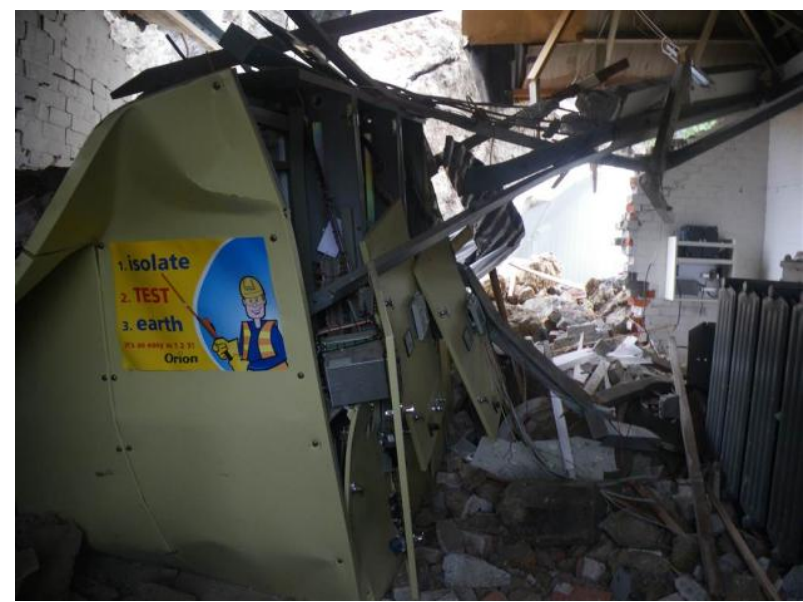

Figure 4: Sumner substation boulder damage.

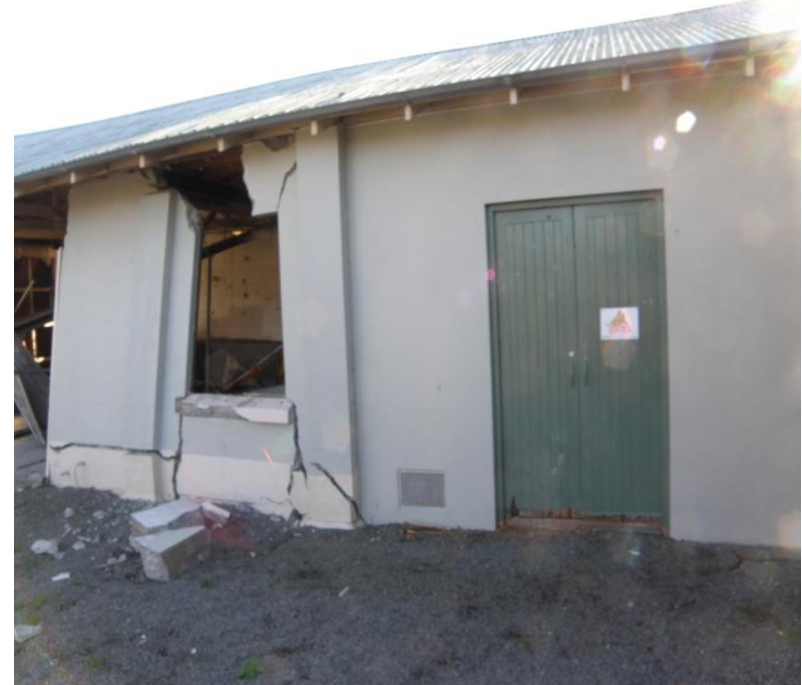

Figure 5: A shared structure with the electrical substation having been seismically strengthened (Redcliffs waterworks substation).

\section{Cable Faults}

A large amount of the underground cable damage occurred to PILCA (paper-insulated lead-covered, armoured) $11 \mathrm{kV}$ cables. The predominant fault that occurred was existing joints pulling apart. These cables are not flexible and some tended to 'kink', causing them to fault (see Fig. 6).

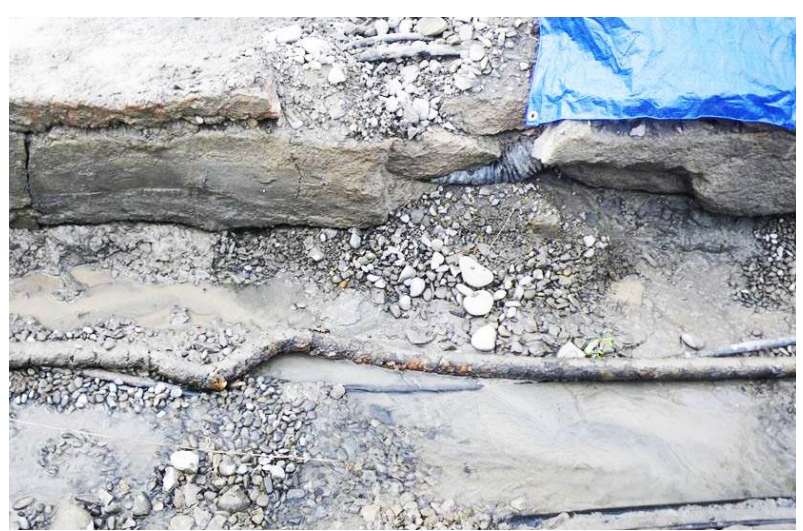

Figure 6: Earthquake damaged $11 \mathrm{kV}$ steel and lead armoured cable, and above embedded in fractured concrete, a damaged $66 \mathrm{kV}$ oil-filled cable. 
Fracturing of the hill land structure also tore joints apart in underground cables (see Fig. 7).

Immediately following the February $22^{\text {nd }}$ earthquake, Orion technicians discovered the $66 \mathrm{kV}$ oil-filled cables from the Bromley GXP to the New Brighton and Dallington substations had both developed multiple faults, and were deemed unrepairable. Contractors were deployed to run a $66 \mathrm{kV}$ overhead circuit from the Bromley GXP to the New Brighton substation as an emergency measure to get power back on in the eastern suburbs as soon as possible. In the space of two weeks a $66 \mathrm{kV}$ overhead line (shown in Fig. 8) and 66/11 kV transformer were installed. If the normal pre-quake process had been observed in this case, the circuit would have taken approximately $1 \frac{1}{2}$ to 2 years to install.

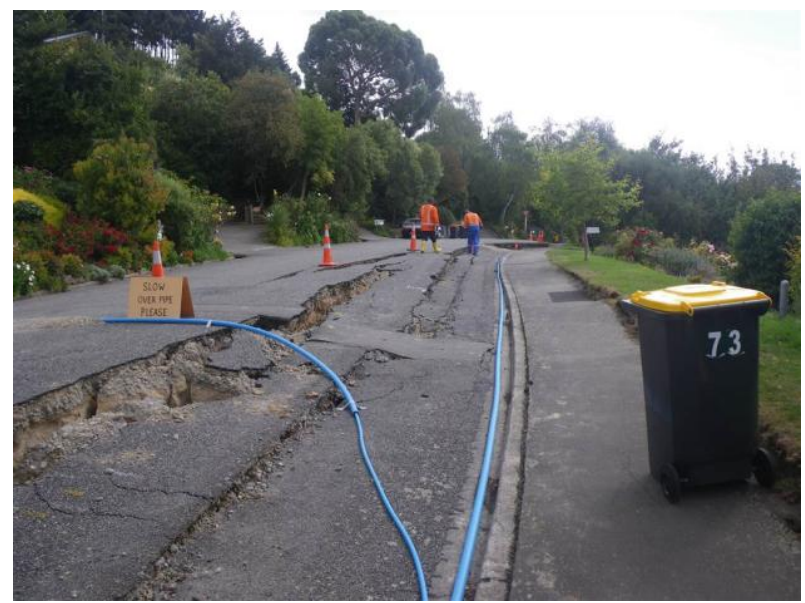

Figure 7: Fracture of land structure on the Port Hills causing underground terminations to be torn apart.

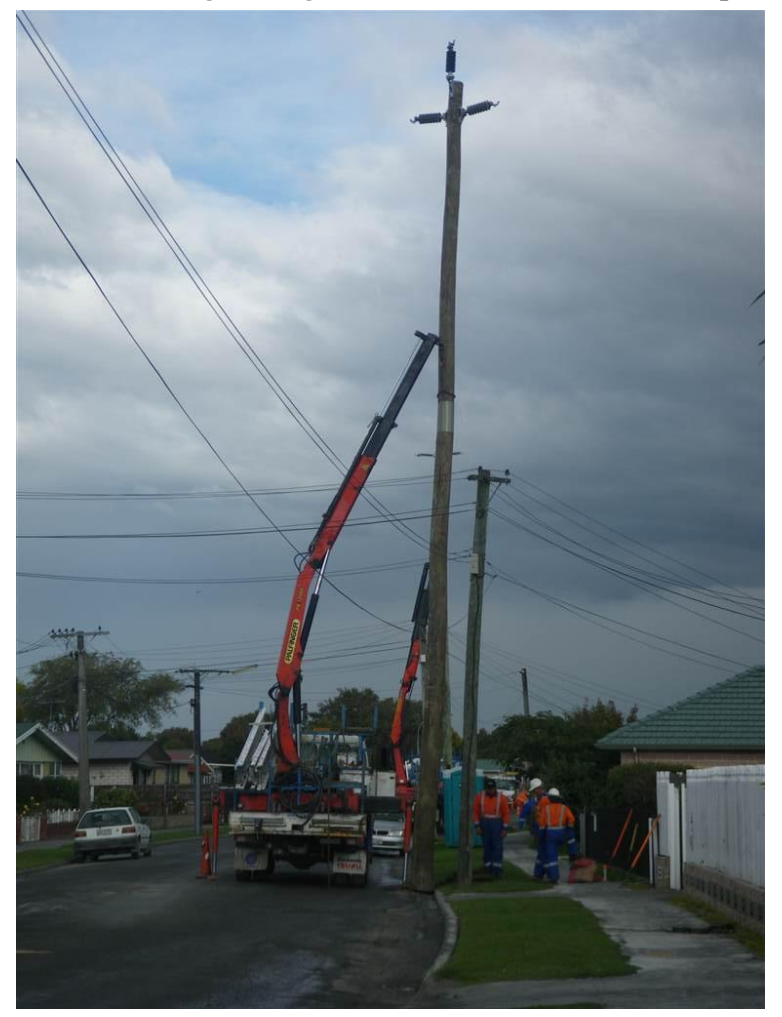

Figure 8: A $66 \mathrm{kV}$ pole being inserted (Note the height difference to the $L V$ pole).

A second $66 \mathrm{kV}$ overhead circuit was commissioned in April to feed the Dallington substation, once again completed in two weeks with 81 poles measuring $15.5 \mathrm{~m}$ in length and sunk 3.5 $\mathrm{m}$ deep in the ground.
The two $66 \mathrm{kV}$ oil filled cable circuits between Addington and Armagh substations were damaged in multiple places, as was the $66 \mathrm{kV}$ XLPE (Armagh to Lancaster substation) cable circuit. The cable repairs were undertaken with the support of local and overseas specialist cable jointers (See Fig. 9). The low voltage network of predominantly polyethylene and polyvinyl chloride (PE and PVC) cables have performed well and suffered fewer faults when compared relative to the observed $11 \mathrm{kV}$ cable networks.

Approximately 600 underground cables have been repaired to date comprising of approximately 1,500 joint repairs. At the height of the underground repair effort, up to 48 cable jointers from Auckland, Northland, Waikato, Wellington, Blenheim and Sydney worked with Connetics' 25 cable jointers on the network at one time, and a total of 82 external jointers over the 4 months following the quake. Fig. 10 shows a schematic of the locations of major cable damage.

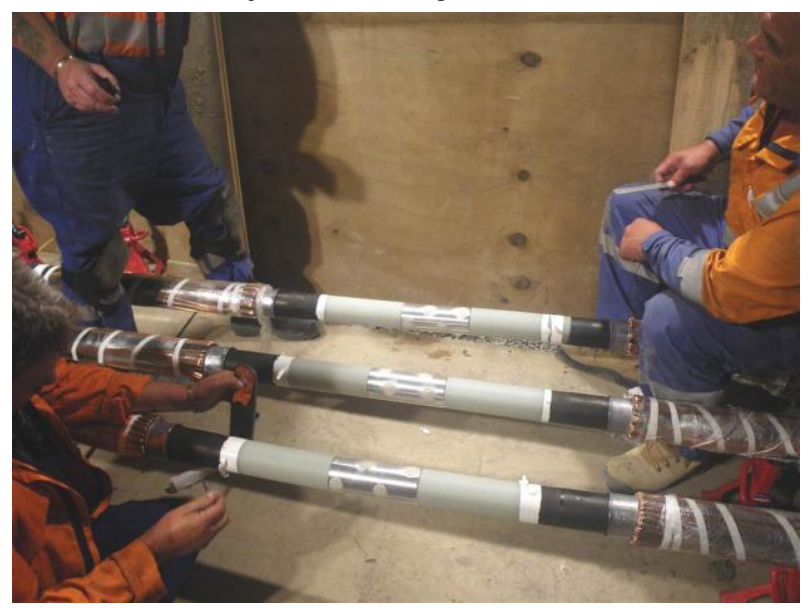

Figure 9: Cable jointers repairing the Armagh-Lancaster $66 \mathrm{kV}$ XLPE cable.

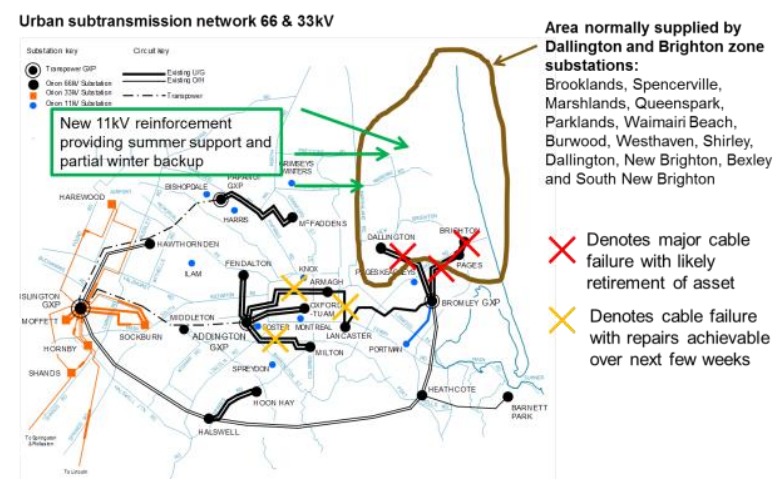

Figure 10: Major Cable Damage (courtesy Orion N.Z. Ltd).

The major fault with overhead lines were predominantly LV issues such as barge boards being ripped off houses and conductors being torn out of terminals due to the ground shaking. Liquefaction caused several poles to sink (see Fig. 11 ), which in turn caused conductors to droop lower and some were torn from terminations by large vehicles. A team of 80 contractors had the overhead network repaired inside of 3 days, freeing up the workforce to work on the aforementioned $66 \mathrm{kV}$ overhead installation. 


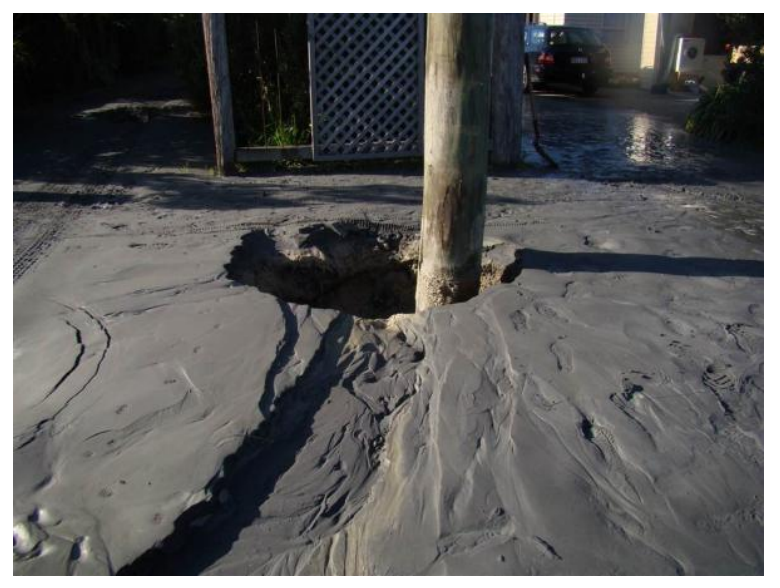

Figure 11: Sunken pole due to liquefaction.

\section{Head Office Damage}

The head office administration building and control centre were badly damaged and unusable. Previous planning had resulted in a hot standby control site and this was invaluable in managing the system after the earthquake. Portacoms were used to replace the offices.

Having electronic version of documents proved valuable for Orion. The earthquake caused pipes to break in the ceilings of offices resulting in water damage to documentation.

\section{Remedial Work}

Besides getting the power on there was an urgent need to ensure the system could cope with the winter loading as winter was approaching. This need was heightened because most homes had their chimneys come down in the earthquakes and hence lost their alternative form of heating and relied on electricity. This involved moving a transformer from an existing substation in the north-west of Christchurch and temporarily using it at the existing New Brighton substation (Fig. 12), while a new replacement substation was being built (Rawhiti substation on Keyes Road, see Fig. 13). Rawhiti substation is approximately $1 / 2 \mathrm{~km}$ away and believed to be on more stable ground. With two major snow-storms during winter, electricity supply was essential.

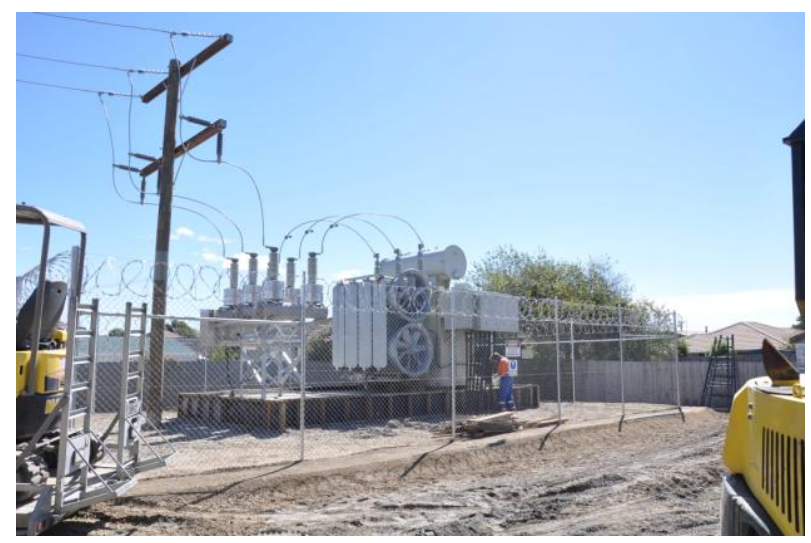

Figure 12: New Brighton temporary site (Courtesy Orion N.Z. Ltd).

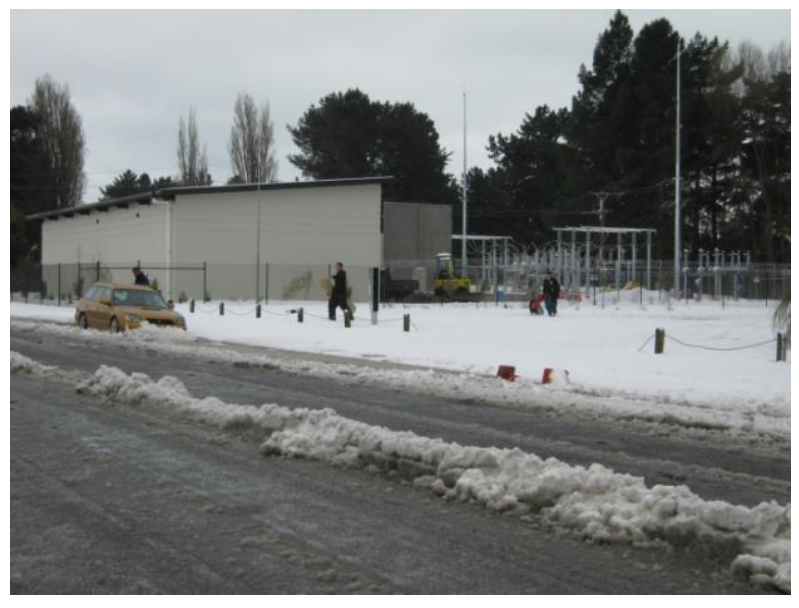

Figure 13: New Rawhiti substation (16 August 2011) (Courtesy Orion N.Z. Ltd).

\section{DAMAGE TO THE DISTRIBUTION NETWORK $\left(13^{\mathrm{TH}}\right.$ JUNE 2011)}

The earthquake of 13 June was magnitude 6.3 Richter scale on the Port Hills fault line with a ground acceleration of $78 \% \mathrm{~g}$ recorded. Regarding the electrical infrastructure the main features were:

- $\quad$ More rock fall/boulder damage (Fig. 14)

- 1 day to restore $90 \%$ of supply

- $\quad$ All power restored within 2 days excluding CBD

- Seismic damage to assets on the Port Hills

- Liquefaction damage to east city assets (Bexley, Dallington \& Avon river area)

- Mainly $11 \mathrm{kV}$ cable damage

- Cost approximately $\$ 3 \mathrm{~m}$

- $\quad 13.7$ m customer minutes lost

- $2 \%$ of the February 22 impact

In Lyttelton volcanic rock walls collapsed which were supporting some LV poles. Fig. 15 shows these LV poles being replaced.

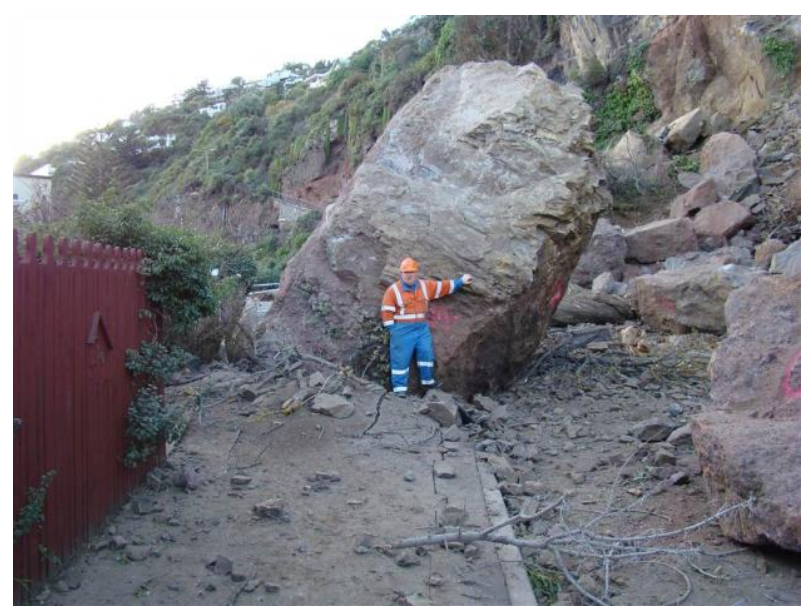

Figure 14: A boulder thrown out of a cliff face that destroyed an $L V$ pole on Heberden Avenue, Sumner.

\section{KEY LESSONS LEARNT}

\section{Importance of Planning}

Although a natural disaster on this scale had not been anticipated, risk planning had considered the two most credible events to be: 
- A magnitude 8 earthquake on the Alpine fault

- A magnitude 7 earthquake on the North Canterbury fault

The risk reduction action taken over the past 15 years showed their value in greatly reducing the network damage. Actions taken included:

- Seismic strengthening of substations

- Improvement to key bridge approaches

- Improvement in design standards

- Establishment of a backup hot-site for Network Control \& Call Centre

Other design features such as ringed $11 \mathrm{kV} \mathrm{HV}$ cable systems and interconnected Low Voltage network helped give flexibility in restoring loads. Use deterministic security standard and the policy of maintaining up to the customer building entry also were beneficial.

Orion N.Z. Ltd is a large enough organization to rapidly increase resources. Three aspects helped in this:

1. Mutual aid arrangements in place with other lines companies

2. Arrangements with suppliers \& contractors

3. Relationships established

The fact that thought had been put into possible disaster scenarios, and plans had been made, was beneficial. Although an unprecedented event occurred, and was different to what had been considered, the process of planning and action was in place. Planning was important to prioritize the restoration work. A few days were needed to assess the situation, the extent of the damage and what would be achievable with the resources available. As the work progresses new information comes to light and plans are revised. Understanding the situation and managing external expectations and solutions is crucial.

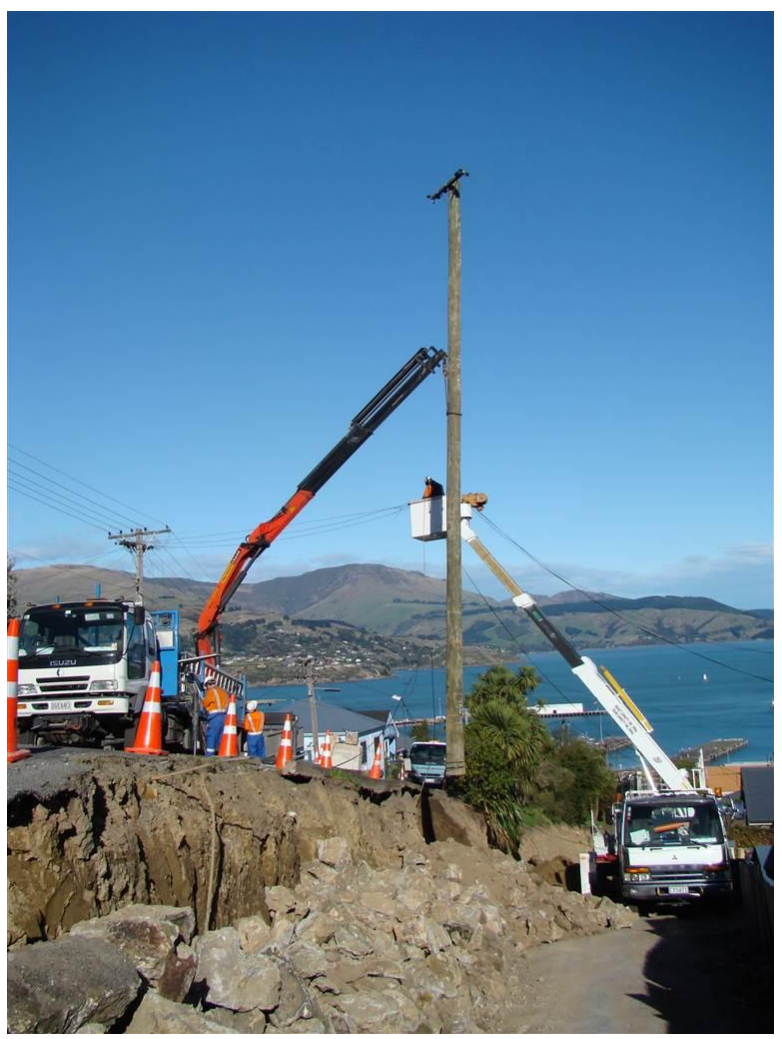

Figure 15: An LV pole in Lyttelton is replaced after the retaining wall collapsed.

\section{Importance of Communication}

Also of great importance is feeding the media with regular updates and indicating when power will be restored to a region. Not only were media releases regular, the Orion website also displayed maps of areas with and without power and some indication of expected restoration time given where possible. Residents wanted to know this, whether they were in an Evacuation Centre, evacuated to family or friends, or 'sticking it out' in their home. Portable buildings such as the Dallington 'Hub' were set up in badly affected areas which residents could easily walk to and use telephone or computers, due to not having these available in their homes.

\section{Human Resources}

Managing human resources is critical at times like these. A great effort is needed to support staff so they are free to work on restoring the electricity supply. Staff and their family wellbeing, food, water, safety, security and mundane things such as washing need to be looked after. In one contracting company engineers made a daily run to get the washing done for their staff families. Another contracting company supplied free bottled water, lunches, team building events and BBQs to keep morale high during difficult times in challenging work and home conditions. People cannot work effectively if issues at home are of concern to them. Also this is the benefit of bringing in support from outside the region to help. Although not familiar with the system, they can help alleviate the demands on local technical staff as they do not have the welfare of family living in shattered homes with no water or sewage to worry about. Where possible allow people to perform their normal function, which they are familiar with.

Often where the ground deformation was sufficient to cause electrical cable damage the water and sewage systems were also ruptured. This made for a very unpleasant working environment (shown in Fig. 16). The area was surrounded with water and silt from liquefaction which was mixed with sewage. Giving all electrical workers hepatitis A immunisation was taken as a precaution.

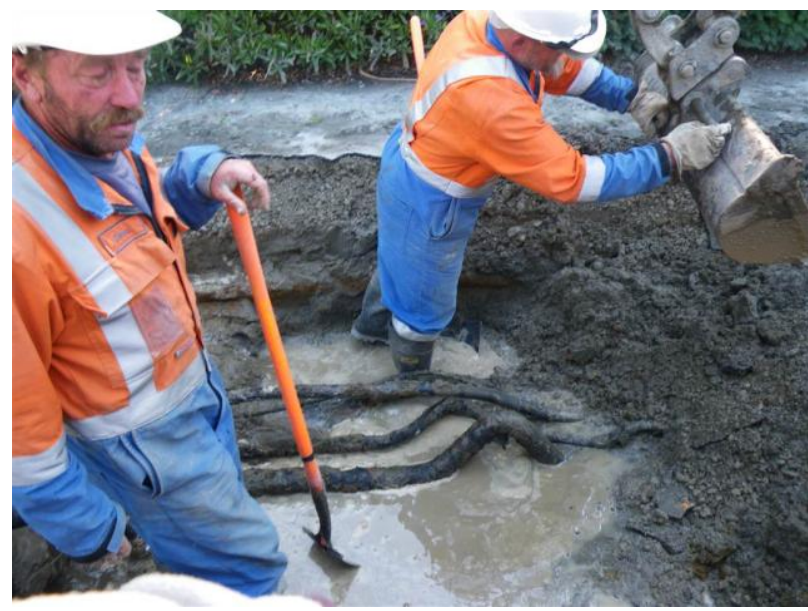

Figure 16: Digging up multiple faulty $11 \mathrm{kV}$ cables.

\section{Physical Resources}

With the $>1,000$ cable joints there was no possible way to ever carry enough spares for an event such as this. Equally important as keeping spare parts is having the supply chains in place to get the materials needed as quickly as possible. For example, once the supply of cable jointing kits in Australasia was exhausted they were flown to New Zealand from the manufacturing plant in Europe. A major joint kit supplier set up an operating base in the cable joiners' room at Connetics with spares readily available. 
Ensuring more than $1 / 2$ tank of fuel in vehicles at all times is essential, as when a disaster such as this occurs, petrol and diesel supplies stop and service vehicles need to travel widely to repair the damage.

\section{Generation}

Temporary generators were used to bolster the network in the eastern suburbs. The optimal size of generators was found to be $400 \mathrm{kVA}-500 \mathrm{kVA}, 415 \mathrm{~V}$. This is because:

- Matches kiosk load

- No transformation necessary

- Not dependent upon possible faulty $11 \mathrm{kV}$ cable network

These are not as reliable as the normal network and it can take a similar time to establish as a single cable repair. Obviously diesel generators are expensive to run. Fuel constraints and delivery issues are an issue for diesel generation, but it does have the ability to expand resources (by deploying more generators) with rapid increase in load demand and if adequate fuel supplies available.

From an economic point of view it was better to purchase these generators rather than lease them. Larger generators (total of 3.8 MVA) were also found useful to minimise demand on key points in the infrastructure that were suffering constraints (zone substations and distribution network). These were installed at QEII in May to bolster supply capacity to the eastern side of the network during winter (Fig. 17).

\section{FUTURE WORK}

In order to add resilience to a fragile system more circuits linking key substations and between the national grid are needed. With the devastation and the redistribution of the population the load characteristics are totally different. Obviously red zoned regions will lose loading and hence the need for infrastructure. The stability of the ground north of Christchurch will mean many will favour settling in this region and hence supply to this region will need to be reinforced in the future. The new $66 \mathrm{kV}$ overhead lines only have a permit for 3 years and alternative arrangements must be put in place in this time. The routes for new underground cables will need to be planned not on the shortest route but by which land is less likely to deform. Experience has shown that land close to streams and rivers (within $\approx 500 \mathrm{~m}$ ) are susceptible to lateral spread. Special attention is therefore needed where cables and services cross waterways on bridges.

Orion N.Z. has released plans for building new substations, laying new cables and reinforcing the system over the next 20 years [3]. Canterbury Earthquake Recovery Authority (CERA) [4] and the Christchurch City Council (CCC) [5] also have a wealth of information on the recovery plans for the city. The author's blog also has a lot of information and many photos documenting the restoration of the electrical infrastructure in Christchurch [6].

There is a need to look at the practice of encasing major cables in weak concrete (or even hard-fill). When ground deformation occurs the concrete cracks, damaging the cable. Putting underground cables in ducts, although requiring derating, would make them somewhat less prone to damage due to ground deformation.

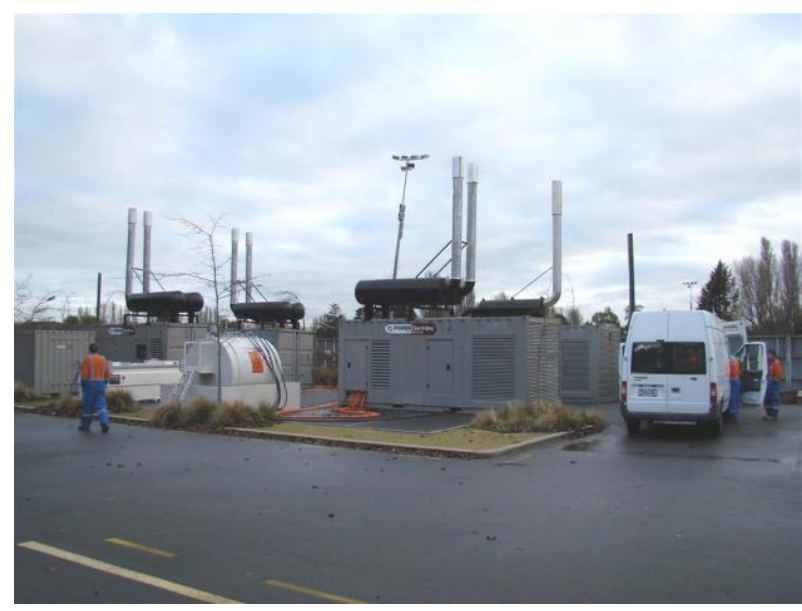

Figure 17: Four diesel generators at QEII park for network strengthening.

\section{CONCLUSIONS}

Even though the event that occurred was significant different to what had been anticipated the fact that planning had occurred aided in the recovery. Some of actions that resulted from this planning significantly reduced the damage to electrical infrastructure and aided recovery. The seismic strengthening dramatically reduced the damage that would have occurred to electrical infrastructure had it not occurred. Having a hot-site for the control centre greatly helped in the recovery process.

\section{REFERENCES}

[1] N.R. Watson, Impact of the Darfield Earthquake on the Electrical Power System Infrastructure, Bulletin of the New Zealand Society for Earthquake Engineering (ISSN No. 1174-9857), Vol. 43, No. 4, December 2010, pp 421424

[2] J. Callan, Canterbury's Seismic Mix, Engineering Insight, IPENZ, May/June 2011, pp. 8-9.

[3] Orion N.Z. Ltd, website: www.oriongroup.co.nz.

[4] Canterbury Earthquake Recovery Authority, website: cera.govt.nz.

[5] Christchurch City Council's recovery plan, web address: www1.ccc.govt.nz/council/proceedings/2011/august/cnclc over11th/13.Attachment1Volume1.pdf

[6] Andrew Massie's blog, www.thunderboltnz.blogspot.com

\section{ACKNOWLEDGMENTS}

The authors are indebted to the staff of Orion N.Z. Ltd, particular John O'Donnell for his generous help. Also the help received from Connetics' staff is acknowledged with thanks, especially those that helped the author during his secondment to Connetics. 